\title{
Cash Incentive Scheme in Nepal: Is It a Panacea to Boost Exports?
}

\author{
Ramesh C. Paudel, Rashmi Shilpakar Rajkarnikar \\ Central Department of Economics, Tribhuvan University, Kirtipur, Nepal \\ Email: ramesh.paudel@alumni.anu.edu.au
}

How to cite this paper: Paudel, R. C., \& Rajkarnikar, R. S. (2020). Cash Incentive Scheme in Nepal: Is It a Panacea to Boost Exports? Theoretical Economics Letters, 10, 1426-1439.

https://doi.org/10.4236/tel.2020.106086

Received: October 28, 2020

Accepted: December 28, 2020

Published: December 31, 2020

Copyright $\odot 2020$ by author(s) and Scientific Research Publishing Inc. This work is licensed under the Creative Commons Attribution International License (CC BY 4.0).

http://creativecommons.org/licenses/by/4.0/

c) (i) Open Access

\begin{abstract}
Nepal's export performance seems unable to meet the expectation of the policy makers for a long time now, and government is trying to adopt many policies and strategies to correct the scenario. Cash incentive to export is one of such mechanisms in Nepal, which was implemented since 2012 to motivate the exporters. This paper analyses the cash incentive mechanism to exports and then investigate the association of this incentive with the export performance using the annual data for the period of 14 years from 2005-2018, in a panel structure, employing the gravity modelling approach for the exports from Nepal to its trading partners. Looking the low number of Nepal's export data reported, we use the mirror export data as the imports are recorded more systematically than the exports. The finding from the estimations suggests that, instead motivating the exporters, the export cash incentive mechanism has a statistically significant negative association with the export performance. The reason for this may be the weakness of properly implementation of the scheme or it may have created some negligence in the firms to produce limited just for targeting the cash incentives so that exports are not really motivated. Also, not all eligible exports received the cash incentive and not all eligible firms have claimed the incentives in practice. However, from the data analysis, it seems that the cash incentive scheme has positively contributed to market diversification to some extent. This situation asks the revision of the schemes or developing the proper mechanism for implementation and on the other way to initiate other types of schemes such as credit incentives tying with production and trade infrastructure to boost the export performance in the country.
\end{abstract}

\section{Keywords}

Export Performance, Export Incentives, and Gravity Modelling Approach 


\section{Introduction}

Nepal's export performance is always of great concerns of the policy makers and the stakeholders due to the export performance is near stagnancy. Nepal experienced an alarming level of trade deficit due to continued mismatch between import and export and this trend is growing year by year. For example, if we have a quick look at Nepal's imports and exports ration, it shows that until about 1999, imports were around double than the exports but this started to incline since then, and as of 2018, it stands at more than five times, meaning that imports are five times greater than the exports. In spite of policy and strategic focus to increase the volume of exports, unwanted imports are increasing each year creating a difficult scenario year by year, particularly, for one and a half decades (See Figure 1).

Considering the situation, as a tool to enhance the export performance, Nepal adopted the cash incentives to exports aiming to reduce trade deficits through the budget announcement from fiscal year 2010/11. This scheme was implemented since 2012 and applied to exporters that, complying with a certain domestic value-added threshold, exported to countries other than India (thus obtaining "convertible currency"). Over the course, the government of Nepal modified the cash incentive scheme in June 2013 to address the exporter's complains regarding their hard time receiving the cash incentive due to the lengthy paper works and the other procedures to be followed for the claim of the incentives. Modified scheme aimed at reducing the costs of filing and allowing firms exporting the selected products. The overall performance of the mechanism for cash incentive for export shows that not all eligible exports received the cash incentive and not all eligible firms have claimed so far. It indicates some problems in proper implementation of the scheme.

Nepal's import has skyrocketed (Figure 1) to more than five folds of exports, and notably this import seems fed by the remittances, particularly, since the early 2000s. The slow growth in export compared to the robust growth in import remains a major concern for Nepal to benefit from trade. Data shows the average

5

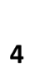

4

3

1

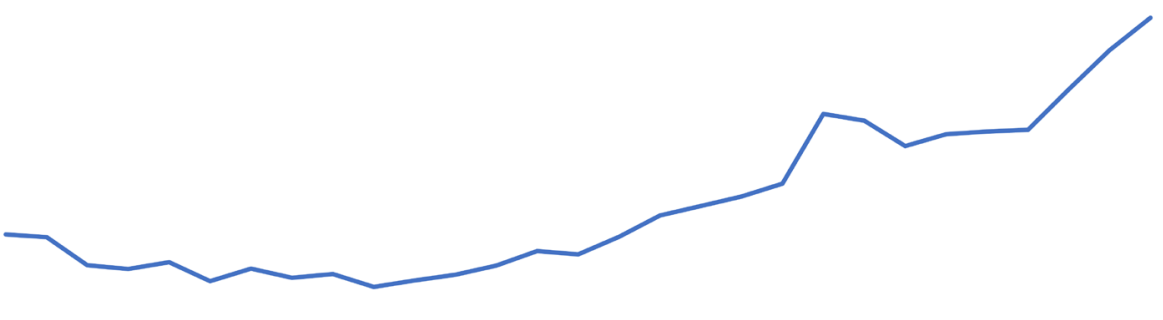

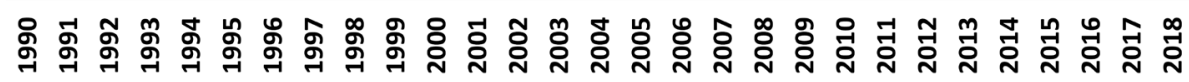
Source: World Bank (2020).

Figure 1. Imports: export ration, 1990-2018. 
growth in export is 4.57 percent whereas average growth in import is 15.39 percent (World Bank, 2020). India occupies the major portion of Nepal's total exports. In terms of export value in an average, export in India is recorded as $61.8 \%$ based on export data between 2012-2018. The United States of America (USA) is observed as the second-largest destination with about 10.0 percent share of the total exports of Nepal.

The major exportable goods of Nepal are woolen goods, carpets (hand-knotted woolen), Nepalese paper and paper products, readymade garments, handicrafts, ornaments, pashmina, pulses, cardamom, medical herbs, etc. Export trade has been accepted as an important mean of poverty reduction and socio-economic development in the global context, and many reforms are done for the better trade environment (Paudel, 2016; Paudel \& Cooray, 2018).

Various forms of incentives, particularly, credit incentives have a substantial contribution for East Asian Miracle, from which established the role of export performance in economic development (Zia, 2008). India started the cash incentives with the name of export subsidies and import replenishment since the late 1960 (Pant, 1972). Both incentive mechanisms have their role to play.

We also examined the role of cash incentives in export performance using annual data for the period of 14 years, from 2005-2018, in gravity modelling framework. We note that the imports data are generally recorded more properly than the exports data. We also observe the low observation of data reported from Nepal's export. Therefore, we use the mirror data, that is, imports of Nepal's partner from Nepal as Nepal's exports. The finding from the estimations suggests that instead motivating the exporters, the export cash incentive mechanism has a statistically significant negative association with the export performance. However, from the data analysis, it seems that the cash incentive scheme has positively contributed to market diversification to some extent. This situation asks the revision of the schemes or to develop the proper mechanism for implementation and to initiate other types of schemes such as credit incentives tying with production and trade infrastructure to boost the export performance in the country.

This paper is organized as follows. The Second Section is about the cash incentive scheme in Nepal covering a brief historical perspective, the Section Three presents the research methodology used in this paper. The Fourth Section focuses to discuss the results and interpretation tying with the literature and the Section Five concludes with some policy inferences based on the findings.

\section{Export Cash Incentive Scheme in Nepal}

\section{Evolving of cash incentive scheme}

The Export Cash Incentive Scheme (ECIS) provision was first announced in the Budget Speech of the fiscal year 2010/11 in April 2010, then its descriptive guidelines; "Export Cash Incentive Directives (ECID), 2012" was issued in 2012 by Nepal Rastra Bank. The ECIS offered at least two percent cash incentive on the value of exports that meet the following two criteria: a) the export transac- 
tion had to incorporate at least 30 percent of domestic value-added, and b) the product under consideration had to be sold in a country other than India. The main reasons to justify the exclusion of exports to India from the scheme, Ministry of Finance (2013) were said: 1) diversification of Nepalese exports away from India, which in 2012 accounted for approximately 68 percent of the country's exports; 2 admirative complexity such as Ministry of Finance (MOF) and the Ministry of Commerce and Supply (MOCS) foresee the risk of reimport and reexport to and from Nepal through a different border point if cash incentives were extended to exports to India. The provision also provisioned that if the share of domestic value-added in the exported product exceeded 50 percent, the subsidy rate to be increased to 3 percent, and would, in turn, reach a maximum of 4 percent if the share of local content incorporated was greater than 80 percent. Government of Nepal's body called the Department of Industry was made responsible for establishing the process/procedures and determining the value addition on the exported product.

Nepal Rastra Bank, upon receiving evidence that the payment for an export transaction in foreign exchange had been deposited in a Nepalese bank would disburse the cash incentive. The total budget allotted to the scheme was rupees 240 million. ECIS was executed on a first-come first-serve basis but the allocated budget was not fully disbursed, only 42.9 percent of the total allocated budget was disbursed as the incentives and only eight exported products claimed for the incentives in the starting year. Out of the eight, products three products were able to receive more than 85 percent of the total disbursed cash incentive. For example, lentil alone received more than 59 percent of the total disbursed cash incentive during the year (Nepal Rastra Bank, 2019).

The incentive scheme was amended based on the exporters' feedback, largely the complains were about the aspect of lengthy and complex procedures for claiming, and the complexity of the domestic value-added calculation required to receive the incentives. For this the new Directive-ECID-2013 was issued making the previous ECID void in June 2013. The main features of the this amendments were: i) reduction in incentive from 2, 3 and 4 percent of the export value in FOB term percent to 1 percent; and ii) introduction of a fast-track working procedures, fixing seven days as the maximum days limit for processing cash incentive claims once the necessary documents have been submitted for the priority products mentioned under Nepal National Trade Integration Strategy (NTIS). This modification has identified and fixed the rates for following 24 industrial and 7 agricultural products eligible for export cash incentives as listed in Table 1.

One important issue was solved as the value-added criteria for agriculture products were removed. The simplified working procedures in new provision allow the firms exporting agricultural products can claim export incentives without proving domestic value-added assessment of their exports. In the case of industrial product exporters also, this provision of value-added criteria made 
Table 1. Eligible products for cash incentives and incentive rates.

\begin{tabular}{lll}
\hline Industrial Products & & Agricultural Products \\
\hline 2\% Subsidy rate & 1\% Subsidy rate & 1\% Subsidy rate \\
\hline Processed coffee & Ready-to-eat chow-chow & Seeds \\
Semi-processed hides \& skins & Bran & Cut flowers \\
Handicraft \& wooden craft & Wheat flour & Fruits \\
Crust skin & Polyester or viscous yarn Polyester textile & Vegetables \\
Handmade paper \& rel. products & Ready-made garments & Ginger \\
Processed honey & Vegetable fat/oil & Cardamom \\
Tea & Transformer & Herbs \\
Carpet \& woolen products & Ball pens & \\
Pashmina \& silk products & Lentils & \\
Processed herbs \& essential oils & Precious \& semi-precious jewelry & \\
& Gold \& silver ornaments & \\
& Turmeric & \\
\hline
\end{tabular}

Source: Nepal Rastra Bank (2013).

easy such as they do not need to conduct new value-added assessments to claim the export incentives once they have been approved. That is the industrial goods' exporters can use a copy of the value-added calculation sheet obtained for previous shipments of the same product to claim the cash incentive from their respective banks, this has made the exporter more easy reducing both number days and documents required to claim the incentives. The new product would need at least $30 \%$ of domestic value-addition and verification of certificate of origin to be eligible for cash incentive and the process for new products value-addition starts with Department of Industry identifying the value-addition. Department after fixing the value-addition rate, recommends it to the Coordination and Monitoring Committee. Based on the value-addition rate identified by the Department, the Committee recommends it for fixation of cash incentive rate to the Cabinet of Ministers. Table 2 presents the data for total budget available, cash incentive distributed and the percent of incentive distributed data collected from Nepal Rastra Bank and these data show the incentive distributed percent has improved only since 2017 but if we look or the overall period, it stands only about 71 percent.

The data shows that on average about 71 percent of cash incentives were claimed during the year 2012-2018. However, the incentive claim shows a increasing trend, many eligible manufacturing and agricultural products are found non-claimed. The reason for non-claimed could be two folds: first, not being able to apply Ministry of Finance (2018), Government of Nepal (2019) and Government of Nepal (2020) for the incentive successfully by completing the necessary administrative procedures to receive the incentive. And second, may be either due to lack of knowledge about the scheme or due to the high costs of filing for the incentive, largely the administrative burden they feel. As filing costs are 
Table 2. Trend of total budget allocation and disbursement for cash incentive.

\begin{tabular}{cccc}
\hline $\begin{array}{c}\text { Year } \\
\text { A }\end{array}$ & $\begin{array}{c}\text { Total Available Budget } \\
\text { B }\end{array}$ & $\begin{array}{c}\text { Export Cash Incentive } \\
\text { Distributed } \\
\text { C }\end{array}$ & $\begin{array}{c}\text { \% of Incentive } \\
\text { Distributed } \\
\text { D = \% (C/D) }\end{array}$ \\
\hline 2012 & $240,000,000$ & $102,869,295$ & $42.9 \%$ \\
2013 & $300,000,000$ & $180,758,831$ & $60.3 \%$ \\
2014 & $300,000,000$ & $378,253,647$ & $126.1 \%$ \\
2015 & $300,000,000$ & $199,880,540$ & $66.6 \%$ \\
2016 & $625,254,720$ & $289,758,830$ & $46.3 \%$ \\
2017 & $334,915,140$ & $211,381,672$ & $63.1 \%$ \\
2018 & $300,000,000$ & $344,248,481$ & $114.7 \%$ \\
Total & $2,400,169,860$ & $1,707,151,296$ & $71.1 \%$ \\
\hline
\end{tabular}

Source: Researchers' calculations based on Nepal Rastra Bank, Forex Section data.

mostly "fixed" (that is, unrelated with the quantities exported), the cost-benefit ratio is larger. The Cabinet of Ministers decided on first amendment of the "Export Cash Incentive Directives, 2013" and issued "Export Grant Disbursement Directives in December 2018" (first amendment) (EGDD), 2019. The amended directive provisioned three to five percent export cash grants for the exportable goods to boost exports. This amendment also revised the list of products for cash incentives taking into consideration in the Nepal Trade Integration Strategy (NTIS)-2016.

The major changes in the amendment EGDD-2019 are: 1) a 5 percent cash incentive to 15 domestic products and 3 percent incentives to 12 products of the export value in FOB terms; 2) the incentives will be provided to the export both in India and the third countries; 3) In order to fetch 5 percent grant, domestic value-addition should be 50 percent, and the for the products of 3 percent grant domestic value-addition should be 30 percent; 4 ) the products of 3 percent grant rate, if its collective trademark is registered at the national level and domestic value addition is 40 percent will be entitled an additional 1 percent grant, could fetch 4 percent grant; and v) For identifying the domestic value-addition of the exported product following formula is proposed:

Value addition $=($ Export FOB price - value of foreign originated material $)$

$$
\times \frac{100}{\text { Export FOB price }}
$$

\section{Impact Prospects on overall contribution in export promotion}

Generally, the overall contribution of the cash incentive scheme in export promotion is analyzed in the three broad level-1) aggregate (macro level); 2) firm level and 3) product level as discuss in the following points:

1) Macro level

Market diversification for exports reducing India focused export was one of the aim of cash incentive schemes. The share of export to India was 68 percent of 
the total export in 2012 that declined almost by 11 percent in 2016 and 2017. The declining trend of export share to India compare to other countries in term of percentage could be viewed as one of the major contributions of the scheme (Table 3).

\section{2) Firm Level}

For the impact of export cash incentive at the firm level comparison between firms claiming the incentives and those did not claim the incentives, but eligible products are made. It could be observed that the firms receiving the incentive are much larger than those that do not receive it but are in principle eligible. Average annual exports of the firms that claimed the incentive consistently throughout the period (2012-2018), is NPR. 23,324,022,622 and that of non-claiming firms is NPR 1,574,367,506 (Table 4). Comparative analysis of performance of incentive recipient and incentive non-recipient firms is given (Table 4).

\section{3) Product Level}

Total of 28 categories of products that were eligible for export cash incentive represented 37.9 percent of the value of total exports in average during 2012-2018 (Table 5). Carpets, polyester yarn, and readymade garments are the most important products, accounting for $28.4 \%$ of total export value in an average of 2012-2018 exports. Lentils, semi-processed skins and handicraft products are second important products with the average share of 4.86 percent of total export value. The other 22 product categories represent less important products $(4.64 \%)$ of total exports, including 5 product categories where no percentage exports are recorded in the data (Table 4).

The export performance of eligible transactions slightly outperformed that of

Table 3. Export status of Nepal (2012-2018).

\begin{tabular}{ccccccc}
\hline Years & $\begin{array}{c}\text { All Country } \\
\text { Export Status }\end{array}$ & \multicolumn{2}{c}{ Export in India } & \multicolumn{2}{c}{ Exports Excluding India } & TOTAL \\
\cline { 2 - 6 } & $\begin{array}{c}\text { Export Value } \\
\text { (in NPR) }\end{array}$ & $\begin{array}{c}\text { Export Value } \\
\text { (in NPR) }\end{array}$ & $\begin{array}{c}\text { \% of } \\
\text { Total }\end{array}$ & $\begin{array}{c}\text { Export Value } \\
\text { (in NPR) }\end{array}$ & $\begin{array}{c}\text { \% of } \\
\text { Total }\end{array}$ & \% \\
\hline 2012 & $75,970,300,977$ & $51,994,717,151$ & 68 & $23,975,583,826$ & 32 & 100 \\
2013 & $83,301,469,150$ & $55,371,464,064$ & 66 & $27,930,005,086$ & 34 & 100 \\
2014 & $90,096,761,672$ & $57,919,709,996$ & 64 & $32,177,051,676$ & 36 & 100 \\
2015 & $75,270,472,526$ & $46,317,567,977$ & 62 & $28,952,904,549$ & 38 & 100 \\
2016 & $74,541,672,390$ & $42,621,370,866$ & 57 & $31,920,301,524$ & 43 & 100 \\
2017 & $76,492,883,505$ & $43,672,146,618$ & 57 & $32,820,736,887$ & 43 & 100 \\
2018 & $85,476,861,650$ & $50,541,679,696$ & 59 & $34,935,181,954$ & 41 & 100 \\
Total & $561,150,421,870$ & $348,438,656,368$ & & $212,711,765,502$ & & \\
Average export market share & $\mathbf{6 2 . 0 9 \%}$ & & $37.91 \%$ & & \\
\hline
\end{tabular}

Source: https://nepaltradeportal.gov.np/web/guest/data-visualization and researchers' calculations based on web data. 
Table 4. Average percentage share of eligible product on total export value (2012-2018).

\begin{tabular}{|c|c|c|c|c|}
\hline S.N. & Cash Incentive Eligible Products & Total Export (NPR) & $\begin{array}{l}\text { Average Annual } \\
\text { Export (in NPR) }\end{array}$ & $\begin{array}{c}\% \text { share of } \\
\text { Total export }\end{array}$ \\
\hline A & Cash Incentives Claimed Products & & & \\
\hline 1. & Carpet and woolen Products & $65,846,135,455$ & $9,406,590,779$ & $14.32 \%$ \\
\hline 2. & Polyester/viscous Yarn/Polyester Textile & $23,903,961,166$ & $3,414,851,595$ & $5.20 \%$ \\
\hline 3. & Readymade Garments & $40,842,237,081$ & $5,834,605,297$ & $0.43 \%$ \\
\hline 4. & Lentil & $11,297,251,058$ & $1,613,893,008$ & $8.88 \%$ \\
\hline 5. & Tea & $1,827,584,719$ & $261,083,531$ & $2.46 \%$ \\
\hline 6. & Semi-processed hide and skin (Crust skin) & $5,659,521,607$ & $808,503,087$ & $0.40 \%$ \\
\hline 7. & Ready to eat chow-chow & $1,294,279,076$ & $184,897,011$ & $1.23 \%$ \\
\hline 8. & Handicraft and wooden craft & $5,376,032,956$ & $768,004,708$ & $0.28 \%$ \\
\hline 9. & Processed herbs and essential oils & $865,719,385$ & $123,674,198$ & $1.17 \%$ \\
\hline 10. & Pashmina and silk products & $1,441,055,542$ & $205,865,077$ & $0.17 \%$ \\
\hline 11. & Wheat flour & $472,986,806$ & $67,569,544$ & $0.02 \%$ \\
\hline 12. & Handmade paper and their products & $3,879,536,350$ & $554,219,479$ & $0.19 \%$ \\
\hline 13. & Processed Coffee & $561,857,157$ & $80,265,308$ & $0.31 \%$ \\
\hline 14. & Herbs & $1,962,881,938$ & $280,411,705$ & $0.05 \%$ \\
\hline 15. & Bran & $108,642,571$ & $15,520,367$ & $0.71 \%$ \\
\hline 16. & Any kind of seed & $3,250,073,526$ & $464,296,218$ & $0.27 \%$ \\
\hline \multirow[t]{2}{*}{17.} & Processed honey & $15,969,597$ & $2,281,371$ & $0.12 \%$ \\
\hline & Total Export Value of Claimed firms & $168,605,725,990$ & $24,086,532,283$ & \\
\hline B & Cash Incentives Non-Claimed Products & & & \\
\hline 18. & Gold and silver ornaments & $1,258,344,538$ & $179,763,505$ & $0.35 \%$ \\
\hline 19. & Vegetable fat/oil & $761,126,484$ & $108,732,355$ & $0.10 \%$ \\
\hline 20. & Precious and semi-precious jewelry & $1,603,544,658$ & $229,077,808$ & $0.01 \%$ \\
\hline 21. & Vegetables & $236,941,731$ & $33,848,819$ & $0.84 \%$ \\
\hline 22. & Ball pen & $46,800,667$ & $6,685,810$ & $0.35 \%$ \\
\hline 23. & Fruits & $1,614,278,312$ & $230,611,187$ & $0.00 \%$ \\
\hline 24. & Turmeric & $2,929,786$ & 614,403 & $0.00 \%$ \\
\hline 25. & Flower (cut flower) & $15,190,793$ & $2,170,113$ & $0.00 \%$ \\
\hline 26. & Dried Ginger & $4,328,474$ & 618,353 & $0.00 \%$ \\
\hline 27. & Ginger & $87,911,325$ & $12,558,761$ & $0.02 \%$ \\
\hline \multirow[t]{3}{*}{28.} & Cardamom & $50,237,118$ & $7,176,731$ & $0.01 \%$ \\
\hline & Total Export Value of non-claimed firms & $5,681,633,886$ & $811,857,845$ & \\
\hline & Total & $174,288,730,911$ & $24,898,390,130$ & $37.90 \%$ \\
\hline
\end{tabular}

Source: Researchers' calculations based on data available at http://nepaltradeportal.gov.np/web/guest/data-visualization. 
ineligible transactions. Eligible transactions are defined as an export of an eligible product to any destination other than India. Even though the incentive scheme became less generous in 2013 and onwards, the values of eligible transactions grew by 2.0 percent in 2013 and 2014; and 5 percent in 2016 (Table 4). The value of ineligible transactions decreased in up to 11 percent in $2016 \mathrm{com}$ pare to that in 2012.

\section{Achievements of incentive mechanism}

If we have a quick look about the overall achievements of the Export Cash Incentive Scheme, we find that the firm's participation in the scheme has been increasing year by year with the highest number in 2017 (194 firms in numbers) as shown in Table 5. As seen from the data in the same table, we notice that carpet and woolen products; readymade garments; and polyester/viscous yarn/polyester textile are the major product of exports in terms of export value (in convertible currencies) during 2012 to 2018. Further, a total of 1.509 billion Rupees was claimed by the eligible exporters indicating a good progress itself. Pashmina and silk products are the number one receiver of export cash incentive (in terms of percentage of the export value) during the same period. The dominancy of the firms claiming incentive is also found in carpet and woolen Products followed by Pashmina and silk products. The dark side is that as indicated in the table, more than 50 percent of the firms exporting eligible products did not participate in the scheme as shown by Table 5 .

\section{Research Methodology}

The research framework of this paper assumes that the exporters' attraction to claim and receiving of export cash incentives will depend the four basic determinants: 1) sufficient budget allocation for the scheme; 2) Administrative requirement for claiming the cash incentives; 3 ) process and procedures established by the government and the banks for providing the incentives; and 4) Effective monitoring mechanisms from the Nepal Rastra Bank, Ministry of Finance, and a proper and meaningful coordination amongst the concerned stakeholders. It is also assumed that effective implementation of the determinants for incentive receipts will result in export growth, market diversification, and employment generation, which in turn will contribute to the outcomes much needed economic development and poverty reduction.

A descriptive method was used to analyze the data followed by an econometric estimation. Descriptive analysis technique was used to assess the concerns and opinions of the concerns of officials regarding the scheme. Before entering econometric estimation, impact analysis based on the descriptive analysis is done to explore the following determinants of the cash incentive scheme: relevancy, effectiveness, efficiency, impact prospects, and sustainability.

Then we move to a standard econometric analysis for assessing the overall effectiveness of the cash incentives in export performance of Nepal. For this purpose, we employ the gravity modeling technique to evaluate the trade flows from 
Table 5. Overall performance of the export cash incentive scheme (2012-2018).

\begin{tabular}{|c|c|c|c|c|c|c|c|c|c|c|c|}
\hline \multirow{2}{*}{ S.N. } & \multirow{2}{*}{ List of eligible Products } & \multirow{2}{*}{$\begin{array}{l}\text { Total Export } \\
\text { (in MPR) }\end{array}$} & \multirow{2}{*}{$\begin{array}{c}\text { Rate of } \\
\text { Incentive }\end{array}$} & \multicolumn{7}{|c|}{ Numbers of Firms Claimed Incentives in } & \multirow{2}{*}{$\begin{array}{l}\text { Incentives } \\
\text { Received }\end{array}$} \\
\hline & & & & 2012 & 2013 & 2014 & 2015 & 2016 & 2017 & 2018 & \\
\hline 1 & Carpet and woolen Products & $65,846,135,455$ & $2 \%$ & 2 & 19 & 89 & 95 & 75 & 98 & 72 & $804,290,964$ \\
\hline 2 & Polyester/viscous Yarn/Polyester Textile & $23,903,961,166$ & $1 \%$ & 2 & 2 & 2 & 3 & 2 & 2 & 0 & $118,710,447$ \\
\hline 3 & Readymade Garments & $40,842,237,081$ & $1 \%$ & 0 & 7 & 7 & 12 & 13 & 22 & 14 & $108,821,948$ \\
\hline 4 & Lentil & $11,297,251,058$ & $1 \%$ & 12 & 13 & 12 & 13 & 5 & 11 & 0 & $101,975,966$ \\
\hline 5 & Tea & $1,827,584,719$ & $2 \%$ & 0 & 1 & 0 & 1 & 4 & 3 & 1 & $4,281,767$ \\
\hline 6 & $\begin{array}{l}\text { Semi-processed hide } \\
\text { and skin (Crust skin) }\end{array}$ & $5,659,521,607$ & $2 \%$ & 2 & 3 & 4 & 8 & 5 & 5 & 5 & $56,301,581$ \\
\hline 7 & Ready to eat chow-chow & $1,294,279,076$ & $1 \%$ & 1 & 1 & 0 & 1 & 0 & 1 & 1 & $13,273,686$ \\
\hline 8 & Handicraft and wooden craft & $5,376,032,956$ & $2 \%$ & 1 & 5 & 8 & 9 & 13 & 16 & 15 & $77,300,186$ \\
\hline 9 & Processed herbs and essential oils & $865,719,385$ & $2 \%$ & 0 & 1 & 2 & 3 & 2 & 0 & 4 & $13,141,760$ \\
\hline 10 & Pashmina and silk products & $1,441,055,542$ & $2 \%$ & 0 & 4 & 26 & 28 & 23 & 32 & 32 & $173,177,569$ \\
\hline 11 & Wheat flour & $472,986,806$ & $1 \%$ & 0 & 1 & 0 & 0 & 0 & 0 & 1 & 946,733 \\
\hline 12 & Handmade paper and their products & $3,879,536,350$ & $2 \%$ & 1 & 1 & 2 & 8 & 3 & 3 & 0 & $31,548,591$ \\
\hline 13 & Processed Coffee & $561,857,157$ & $2 \%$ & 2 & 2 & 0 & 0 & 1 & 1 & 0 & $2,379,765$ \\
\hline 14 & Herbs & $1,962,881,938$ & $1 \%$ & 0 & 1 & 0 & 0 & 1 & 0 & 0 & 917,639 \\
\hline 15 & Bran & $108,642,571$ & $1 \%$ & 2 & 1 & 0 & 0 & 0 & 0 & 0 & $1,759,447$ \\
\hline 16 & Any kind of seed & $3,250,073,526$ & $1 \%$ & 0 & 1 & 1 & 1 & 0 & 0 & 0 & 342,434 \\
\hline 17 & Processed honey & $15,969,597$ & $1 \%$ & 0 & 0 & 0 & 1 & 0 & 0 & 0 & 253,921 \\
\hline 18 & Gold and silver ornaments & $1,258,344,538$ & $1 \%$ & 0 & 0 & 0 & 0 & 0 & 0 & 0 & 0 \\
\hline 19 & Vegetable fat/oil & $761,126,484$ & $1 \%$ & 0 & 0 & 0 & 0 & 0 & 0 & 0 & \\
\hline 20 & Precious and semi-precious jewelry & $1,603,544,658$ & $1 \%$ & 0 & 0 & 0 & 0 & 0 & 0 & 0 & 0 \\
\hline 21 & Vegetables & $236,941,731$ & $1 \%$ & 0 & 0 & 0 & 0 & 0 & 0 & 0 & 0 \\
\hline 22 & Ball pen & $46,800,667$ & $1 \%$ & 0 & 0 & 0 & 0 & 0 & 0 & 0 & 0 \\
\hline 23 & Fruits & $1,614,278,312$ & $1 \%$ & 0 & 0 & 0 & 0 & 0 & 0 & 0 & 0 \\
\hline 24 & Turmeric & $2,929,786$ & $1 \%$ & 0 & 0 & 0 & 0 & 0 & 0 & 0 & 0 \\
\hline 25 & $\begin{array}{l}\text { Flower } \\
\text { (cut flower) }\end{array}$ & $15,190,793$ & $1 \%$ & 0 & 0 & 0 & 0 & 0 & 0 & 0 & 0 \\
\hline 26 & Dried Ginger & $4,328,474$ & $1 \%$ & 0 & 0 & 0 & 0 & 0 & 0 & 0 & 0 \\
\hline 27 & Ginger & $87,911,325$ & $1 \%$ & 0 & 0 & 0 & 0 & 0 & 0 & 0 & 0 \\
\hline \multirow[t]{2}{*}{28} & Cardamom & $50,237,118$ & $1 \%$ & 0 & 0 & 0 & 0 & 0 & 0 & 0 & 0 \\
\hline & TOTAL & $174,287,359,876$ & & 25 & 63 & 153 & 183 & 147 & 194 & 145 & $1,509,424,404$ \\
\hline
\end{tabular}

Source: Researchers' calculations based on Nepal Rastra Bank (Forex Section) data and web data available at https://nepaltradeportal.gov.np/web/guest/data-visualization. 
Nepal to its trading partners. In the original form of the gravity modeling technique as developed by Tinbergen (1962) to evaluate the role of trading countries' GDP, population and the distance between their major cities were only the variables included in the model. Later, this model is widely used augmenting it to identify the determinants of trade flows adding many other variables as discussed in Paudel and Cooray (2018). In fact, it has been a workhorse among the international trade economists because of its techniques and no other alternative models available to evaluate the trade flows between countries to countries. Thus, gravity model of the following form is used as the benchmark model in this paper:

$$
\begin{aligned}
\operatorname{LEXPORT~}_{i j, t}= & \alpha+\beta_{1} \operatorname{LGDP}_{i^{*} j, t}+\beta_{2} \operatorname{LPOP}_{i^{*} j, t}+\beta_{3} \text { LDIST }_{i j, t}+\beta_{4} \operatorname{INCENTIV~}_{i, t} \\
& +\beta_{5} \text { TARIFF }_{j, t}+\beta_{6} \text { GOVRNANCE }_{i, t}+\beta_{7} \operatorname{LLOCK}_{j, t}+\epsilon_{i j, t} \cdots
\end{aligned}
$$

where, dependent variable is total export from Nepal to partner countries by year for the period of 2005 to 2018 . The independent variable includes the product of the GDP of importer and exporter then converted to natural log. Similarly, the population variable is constructed. The log of distance is used to proxy the costs of trade between countries, and incentive rate is used to identify the association of the exports incentive with export performance and measured in percent. The tariff variable is constructed with the weighted average mean tariffs for all goods imported in Nepal's trading partners and the governance variables is the quality of governance indicator of Nepal. First three independent variables are in natural log form, and the incentive and tariffs are measured in percent term and the governance is an index. The landlockedness of importer has been included as a dummy variable in the model as this may deter the imports from Nepal, that is, Nepal's exports following Paudel (2014).

For the robustness check, the benchmark model as of Equation (1) has been tested with alternative specifications removing the few variables in the model as specified in the results table. Another variable is to detect the impact of partner's Landlockedness. The expected sign of the main variable of interest INCENTIV is positive.

This study mainly uses the secondary data collected from different sources as cited in the relevant places, and for the econometric estimation, we use the data from United Nations trade data base jointly published with the World Bank (WITS, 2020). Looking the low number of Nepal's exports data reported while checking the data, we use the mirror export data as the imports are recorded more systematically than the exports (Paudel \& Burke, 2015; Paudel \& Cooray, 2018). For example, Nepal's export may not be reported properly as the export recording mechanism is poor compared to import recording system, such as, via customs. But India's import from Nepal is recorded. And, that India's import from Nepal becomes the exports of Nepal in mirror data. For analysis of the cash incentives mechanism, existing and previous cash incentives directives/circulars of Nepal Rastra Bank were reviewed. This study covers the period from 2005 to 
2018 and the data for cash incentives for the period from 2012 to 2018 . The trade data are collected from WITS (2020) and the cash incentives disbursement were collected from Nepal Rastra Bank.

\section{Result and Discussion}

As our model incorporates both time variant and invariant gravity variables, however our main variable of interest-export incentive is time variant but the variation is very low, largely we have to rely on the Random Effect (RE) estimation despite the Fixed Effect (FE) estimation is preferred in econometrics because of the country specific fixed effects in the variables. Therefore, our strategy here is to start with the FE so that we can gauge the RE results and their credibility of the estimation. The econometric results are presented in Table 6, on which the first column results are from FE estimation, second, third and fourth columns are from RE estimation. In the FE results, distance and landlockedness dummy are dropped as they are time invariant variables.

The results for export cash incentives results are positive but the coefficients are very small and statistically not significant under FE estimation method. But

Table 6. Gravity model estimation results, random effect, 2005-2018.

\begin{tabular}{|c|c|c|c|c|}
\hline & (FE) & (RE) & (RE) & (RE) \\
\hline \multirow[t]{2}{*}{ Trading partners' population-log } & 0.429 & $0.216^{\star *}$ & $0.217^{\star \star}$ & $0.189^{* *}$ \\
\hline & $(0.527)$ & $(0.100)$ & $(0.101)$ & $(0.090)$ \\
\hline \multirow[t]{2}{*}{ Trading partners' GDP-log } & $0.200^{* *}$ & $0.403^{* * *}$ & $0.401^{* * *}$ & $0.392^{* * *}$ \\
\hline & $(0.091)$ & $(0.065)$ & $(0.065)$ & $(0.062)$ \\
\hline \multirow[t]{2}{*}{ Distance between populous cities } & (dropped) & $-0.685^{\star *}$ & $-0.685^{\star *}$ & $-0.604^{* *}$ \\
\hline & & $(0.297)$ & $(0.297)$ & $(0.294)$ \\
\hline \multirow[t]{2}{*}{ Export incentives-percent } & 0.004 & $-0.082^{\star *}$ & $-0.081^{* *}$ & $-0.120^{* * *}$ \\
\hline & $(0.032)$ & $(0.032)$ & $(0.032)$ & $(0.028)$ \\
\hline \multirow[t]{2}{*}{ Importers' tariff rates-percent } & -0.008 & -0.015 & -0.015 & \\
\hline & $(0.030)$ & $(0.027)$ & $(0.027)$ & \\
\hline \multirow[t]{2}{*}{ Nepal's governance index } & $-0.337^{* *}$ & $-0.270^{*}$ & $-0.271^{\star}$ & \\
\hline & $(0.152)$ & $(0.148)$ & $(0.148)$ & \\
\hline \multirow[t]{2}{*}{ Partners' landlockedness } & (dropped) & 0.007 & & \\
\hline & & $(0.425)$ & & \\
\hline Number of observations & 1048 & 1048 & 1048 & 1156 \\
\hline Number of groups & 126 & 126 & 126 & 139 \\
\hline F/Wald-statistics & 4.50 & 109.10 & 105.11 & 100.32 \\
\hline R-squared & 0.49 & 0.58 & 0.56 & 0.52 \\
\hline
\end{tabular}

Note: ${ }^{* *},{ }^{* *}$ and ${ }^{*}$ denotes that the coefficients are significant at $1 \%, 5 \%$ and $10 \%$ level of significance, respectively. The robust standard errors are reported in the parenthesis. Data sources: World Bank (2020), WITS (2020) and CEPII (2019). 
the results from RE estimation suggest that export incentive has, in fact, no positive contribution in export performance. The results show that a 10 percent increase in incentives causes to decline the exports by about one percent on average holding other variables in the model constant. These results indicate that the incentive provision, at least if it has not caused to decline, has not contributed the export performance as expected by the policy makers as its current form. Therefore, it seeks the urgent attention to review for proper implementation as it aims to be caught up for the growth of exports.

The results for other variables in the model follow the standard literature, and Nepal's export performance is generally based on market size, both in term of population and GDP size of the partners. The negative impact of distance is very high and statistically significant following the findings from the literature. The estimated results are consistent among all specifications of the model as can be seen in the different columns of RE estimation results in Table 6. Partner's landlockedness do not have such significant impact as Nepal's trade is focusing on light and high-value products. The governance index has a negative sign against our expectation, but it seems true as the index is almost invariant for many years and remains 2.5 and 3 for the entire duration, indicating a room to improve the quality of governance meaningfully to boost the export performances. Therefore, it seems that, as of now, export cash incentives scheme is not a panacea to boost the export performance and meet the expectation of the policy makers and stakeholders of the export trade in the country.

\section{Conclusion}

Nepal's export performance seems a big challenge to policy makers and stakeholders as the efforts are not working as expected. Trade deficit is increasing alarmingly and the share of Nepal's exports in the world is declining. In this background, export cash incentive mechanism is one of the government initiations to improve the export performance in Nepal. Because of this mechanism, export diversification has been widening and the dependency in India for exports has been reduced to some extent but still the dominancy of exports to India remains strong. Non-participation of eligible exporting firms in the scheme could be an indication mis-match/complexity in implementation modality (fixing of value-addition and process of claim application) which might have discouraged not only the small firms (of agriculture products and some of the industrial products) but also, firms exporting most important and second most important products in participation in the scheme. One way might be the focus to producers instead of exporters.

Can the export cash incentive be a panacea for export performance in Nepal? We tried to answer this question with the econometric estimation using the standard gravity modelling technique in the panel data for exports from Nepal to the trading partners for the period of 2005-2018. The finding from the estimations suggests that instead motivating the exporters, the export cash incentive 
mechanism has a statistically significant negative association with the export performance. This situation asks the revision of the schemes or to develop the proper mechanism for implementation and to initiate other types of schemes such as credit incentives and financing tying with production and trade infrastructure to boost the export performance in the country.

\section{Conflicts of Interest}

The author declares no conflicts of interest regarding the publication of this paper.

\section{References}

CEPII (2019). The CEPII Gravity Dataset. http://www.cepii.fr/anglaisgraph/bdd/gravity.asp

Government of Nepal (2019). Working Procedure of Cash Incentive Mechanism of Nepal. Kathmandu, Nepal.

Government of Nepal (2020). Revised Working Procedure of Cash Incentive Mechanism of Nepal First Amendment. Kathmandu, Nepal.

Ministry of Finance (2013). The Economic Survey. Ministry of Finance, Government of Nepal.

Ministry of Finance (2018). The Economic Survey. Ministry of Finance, Government of Nepal.

Nepal Rastra Bank (2013). Circular Number 594. Kathmandu, Nepal: Nepal Rastra Bank.

Nepal Rastra Bank (2019). Quarterly Economic Bulletin. Kathmandu, Nepal: Research Department of Nepal Rastra Bank.

Pant, N. (1972). What Sort of Incentives for Exports? Economic and Political Weekly, 7, 465-470.

Paudel, R. C. \& Burke, P. J. (2015). Exchange Rate Policy and Export Performance in a Landlocked Developing Country: The Case of Nepal. Journal of Asian Economics, 38, 55-63. https://doi.org/10.1016/j.asieco.2015.04.003

Paudel, R. C. \& Cooray, A. (2018). Export Performance of Developing Countries: Does Landlockedness Matter? Review of Development Economics, 22, e36-e62. https://doi.org/10.1111/rode.12389

Paudel, R. C. (2014). Export Performance in Developing Countries: A Comparative Perspective. Canberra: Arndt-Corden Department of Economics, Crawford School of Economics, and Government, ANU College of Asia and the Pacific.

Paudel, R. C. (2016). Liberalization Reform and Export Performance of India. Journal of Economics and Economic Education Research, 17, 201.

Tinbergen, J. (1962). Shaping the World Economy: Suggestions for an International Economic Policy. New York: Twentieth Century Fund.

WITS (2020). Trade Data (UN Comtrade).

http://wits.worldbank.org/WITS/WITS/AdvanceQuery/RawTradeData/QueryDefinitio $\underline{\text { n.aspx?Page }=\text { RawTradeData. }}$.

World Bank (2020). World Development Indicator. https://databank.worldbank.org/source/world-development-indicators.

Zia, B. H. (2008). Export Incentives, Financial Constraints, and the (MIS) Allocation of Credit: Micro-Level Evidence from Subsidized Export Loans. Journal of financial economics, 87, 498-527. https://doi.org/10.1016/j.jfineco.2006.12.006 